\title{
Reproductive potential in female cattle discarded as infertile
}

\author{
F. L. M. Dawson \\ Veterinary Investigation Centre, Ministry of Agriculture, Fisheries and Food, \\ Madingley Road, Cambridge, U.K.
}

\begin{abstract}
Summary. Dairy cattle were served at consecutive heats up to three times each; they were then slaughtered, and the genital tracts were examined.

Seventy-four cattle had been discarded from herds because they had not bred; 14 had never calved, and 14 were primiparous. Of these 28 animals, $12(43 \%)$ conceived readily, and had normal pregnancies; normal genital tracts were found at slaughter. Eleven of the 16 animals that did not conceive had normal genitalia. The remaining 46 animals were mature cows, with a mean parity of $4.9 ; 9(19.6 \%)$ became pregnant and had live embryos at autopsy, while in 7 other cows $(15.2 \%)$ conception had been followed by embryonic death. Five of the uteri associated with these 16 conceptions showed pathological changes. Thirty of the 46 mature cows $(65 \%)$ did not conceive; 12 $(40 \%)$ had normal genitalia, and $18(60 \%)$ showed severe pathological changes in the uterus and/or oviduct. Nine 'control' cows discarded because of poor milk yield were infertile, but 5 cows, discarded for various other reasons, all bred normally.
\end{abstract}

\section{Introduction}

Many authors have indicated that failure to breed is an important reason for discarding animals from herds, particularly of dairy cattle. For example, Beynon \& Howe (1974) suggested a value of $35 \%$ of all discards in a representative sample survey. Smith $(1958,1969)$, however, considered that many of the cows classified as infertile had probably only been served once or twice, before disposal; and David, Bishop \& Cembrowicz (1971) claimed that probably few cows remain infertile permanently, or for long periods - they had observed only $8 \%$ of genital abnormalities visible to the naked eye in random abattoir surveys. Little information has been published about the extent of the effort made by an owner to obtain breeding of his animals before discarding them. Donaldson (1971) conducted a small trial with beef cows that were not pregnant at the end of the breeding season; 18 of the 38 cows had normal embryos after being kept with a bull for 39 days. In a study of 41 animals which had been discarded as infertile from 6 dairy farms over a 5-year period, Dawson (1972) found that 12 out of 21 nulli- and primiparous cattle conceived readily, while only 2 of 20 multiparous cows did so. Twelve of the mature cows had chronic inflammation of the genital tract.

The present paper is an extension of the 1972 study in an attempt to assess (1) the effort made to breed an animal before it is discarded as infertile and (2) the fertility potential of the cow after it has left the herd.

\section{Materials and Methods}

The 88 discarded cattle from 45 brucellosis-free farms included 60 Guernseys and Jerseys, 21 Friesians, and 7 of other breeds. Seventy-four of the animals had been discarded as infertile after an average of 5 services each (Table 1). The number of services per cow was lower for the multiparous animals, because 9 of the cows were acyclic or had been served only 1-3 times at intervals exceeding 3 months. Thirty-nine of the 74 animals $(53 \%)$ had received on-farm veterinary treatment for infertility during the period preceding discard. Fourteen cattle discarded for reasons other than failure to breed (see 'Results') were observed as 'controls'.

None of the cows was treated in any way after receipt, but all were to be served three times at consecutive heats unless conception occurred. The first experimental service was $12-15$ months after 
Table 1. The reproductive status of the dairy cattle used in the present study

\begin{tabular}{ccc}
\hline Parity & $\begin{array}{c}\text { Number of } \\
\text { animals }\end{array}$ & Mean no. of services/cow* \\
\hline 0 & 14 & $7 \cdot 7$ \\
1 & 14 & $6 \cdot 4$ \\
$2-9$ & 46 & $4 \cdot 3$ \\
Total & 74 & $5 \cdot 3$ \\
\hline
\end{tabular}

* Since the last calving.

the last calving for cows, which had therefore stopped lactating, and a mean of 12 months after the first on-farm service for heifers. Free-range cross-bred bulls were used, with the cows run at grass during most of the year. During winter the same bulls were used when oestrus was detected (by clinical methods) in cows tied in stalls indoors. Rectal and vaginal examinations were carried out at weekly or shorter intervals throughout a study on each animal of not less than 2 months. After slaughter, the genital tract was dissected out and histological sections were prepared from one horn of the uterus and from three regions of each oviduct. Horse-blood agar plates were inoculated from the endometrium of each horn and the epithelium of each oviduct and incubated at $37^{\circ} \mathrm{C}$ for $48 \mathrm{~h}$ in air.

\section{Results}

Only 67 of the 88 animals were studied as planned; study of the other animals was incomplete because (a) one cow died (hydronephrosis), (b) pathological changes severe enough to preclude reproduction were detected in the genitalia at rectal palpation ( 2 cows) and (c) some oestrous periods occurring while the cows were stalled during cold weather were not detected ( 18 cows).

\section{Control cows}

Nine of these had been discarded because of poor milk yield, but only 2 of them conceived (Table 2). Severe endometritis was observed in Cows 246 and 516 (which did not conceive), but bacteria (coliform-type organisms and non-haemolytic cocci) were obtained only from cultures of endometrium from Cow 530 (which conceived normally). The 5 cows discarded because of mastitis, lameness, actinomycosis, and herd disposal all conceived after an average of 1.8 services per conception (Table 2).

\section{Nulliparous and primiparous cattle}

There were 14 heifers and 14 primiparous animals in this group, and 6 cows and 6 heifers (43\%) conceived to experimental service, 11 animals to the first service and 1 to the second, i.e. 1.08 services/conception. All the pregnancies appeared normal at slaughter and genital tract morphology was normal. The other 16 animals received 3 (10 animals), 2 (1), 1 (4) and 0 (1 heifer which did not cycle) services, but none conceived. The genital tract was normal in 11 of the animals, but 3 exhibited chronic endometritis and two had chronic endometritis and unilateral endosalpingitis. The appearance of the genital tract lesions mentioned in this paper in general conformed to previous descriptions (Dawson, 1958, 1963). No bacteria were recovered from the oviducts of any animal in this group, and uterine cultures were negative for 17 of the animals. A few haemolytic staphylococci were recovered from the uterus of 2 nulliparae that conceived, but all other recoveries (from 3 animals that conceived and from 8 that did not, including 3 of the 5 cattle with pathological changes), were of non-haemolytic organisms characteristic of those normally present in the bovine uterus (Gunter $e t$ al., 1955). 
Table 2. Records of experimental service of the 'control' cows and of those mature dairy cows, discarded as infertile, which conceived in the present study

\begin{tabular}{|c|c|c|c|c|c|c|}
\hline \multirow[b]{2}{*}{ Cows } & \multirow[b]{2}{*}{ Breed } & \multirow[b]{2}{*}{ Parity } & \multicolumn{3}{|c|}{ Experimental services } & \multirow[b]{2}{*}{ Comment } \\
\hline & & & 1st & 2nd & 3 rd & \\
\hline \multicolumn{7}{|c|}{ 'Control' animals } \\
\hline $246^{*}$ & $\mathbf{G}$ & 4 & $t$ & - & - & \multirow{9}{*}{$\begin{array}{l}\text { Dead membranes without fetu } \\
\text { Normal pregnancy at } 68 \text { days }\end{array}$} \\
\hline $340^{*}$ & $\mathbf{G}$ & 3 & + & - & - & \\
\hline $370^{*}$ & G & 5 & - & - & - & \\
\hline $378^{*}$ & $\mathbf{G}$ & 3 & + & - & - & \\
\hline $492^{*}$ & $\mathrm{~J}$ & 6 & + & + & + & \\
\hline $503 *$ & $\mathrm{~J}$ & 9 & - & - & - & \\
\hline $516^{*}$ & $\mathbf{F}$ & 2 & + & + & + & \\
\hline $521^{*}$ & $\mathrm{~F}$ & 6 & + & + & & \\
\hline $530^{*}$ & $\mathbf{F}$ & 8 & + & + & & \\
\hline $332 \dagger$ & G & 7 & + & - & $\rightarrow$ & Normal pregnancy at 21 days \\
\hline $483 \dagger$ & $\mathbf{G}$ & 6 & + & + & - & Normal pregnancy at 48 days \\
\hline $497 \dagger$ & G & 1 & + & + & - & Normal pregnancy at 63 days \\
\hline $501+$ & $\mathbf{J}$ & 1 & + & - & - & Normal pregnancy at 82 days \\
\hline $309 \dagger$ & $\mathbf{G}$ & 8 & + & + & + & Normal pregnancy at 94 days \\
\hline \multicolumn{7}{|c|}{ Multiparous cows } \\
\hline 285 & $\mathbf{G}$ & 3 & + & - & - & Normal pregnancy at 10 days \\
\hline 238 & $\mathbf{G}$ & 9 & + & - & - & Normal pregnancy at 25 days \\
\hline 337 & G & 8 & + & + & - & Normal pregnancy at 27 days \\
\hline 479 & $\mathbf{G}$ & 6 & + & - & - & Normal pregnancy at 42 days \\
\hline 486 & G & 9 & + & + & + & Normal pregnancy at 47 days \\
\hline 499 & $\mathbf{F}$ & 2 & + & - & - & Normal pregnancy at 65 days \\
\hline 525 & $\mathbf{F}$ & 7 & + & - & - & Normal pregnancy at 77 days \\
\hline 473 & $\mathbf{J}$ & 7 & + & - & - & Normal pregnancy at 120 days \\
\hline 463 & G & 2 & + & - & - & Normal pregnancy at 140 days \\
\hline 290 & $\mathbf{J}$ & 3 & + & + & + & Dead embryo at 21 days \\
\hline 361 & $\mathrm{G}$ & 2 & + & - & - & Dead embryo at 26 days \\
\hline 289 & G & 5 & + & - & - & Dead embryo at 30 days \\
\hline 484 & F & 5 & + & + & + & Dead embryo at 37 days \\
\hline 506 & $\mathbf{F}$ & 9 & + & + & + & Dead embryo at 48 days \\
\hline 527 & $\mathbf{F}$ & 6 & + & - & - & Dead embryo at 49 days \\
\hline 254 & $\mathbf{A}$ & 4 & + & - & - & Dead fetus at 120 days \\
\hline
\end{tabular}

$\mathbf{A}=$ Ayrshire; $\mathbf{F}=$ Friesian $; \mathrm{G}=$ Guernsey $\mathbf{J}=$ Jersey.

* These animals were discarded because of poor milk yield.

$\dagger$ Reasons for discard of these animals: lameness, mastitis, actinomycosis, herd disposal.

\section{Multiparous cows}

The average parity of these animals was 4.9 . For the 9 cows that conceived and were carrying a live fetus at autopsy (Table 2) the service to conception ratio was $1 \cdot 33$. However, 3 of the animals (Nos 238, 285 and 337) were affected with endometritis, and these pregnancies, of 10, 25 and 27 days at slaughter, might not have continued normally to term. A further 7 cows conceived after an average of 1.9 services each, but in all of them the embryos were dead at autopsy (Table 2). Two of these animals had severe chronic endometritis.

None of the 30 remaining cows conceived: 2 did not cycle, 14 each received 3 experimental services, 5 received 2 and 9 only 1 service. Of these 30 cows, 18 showed severe histopathological changes of the genital tract, mainly chronic endometritis, bursitis, and endosalpingitis. In 4 of these animals, bacteria that were perhaps associated with the disease changes were still present: Corynebacterium pyogenes in high density was isolated from uterine pus of 2 cows, haemolytic staphylococci from a third (uterus) and fourth (oviduct) cow, and non-haemolytic bacteria from a further 6 cows. 


\section{Discussion}

Although there is evidence that Channel Island cattle are (very slightly) less fertile than other breeds under British conditions (e.g. Wijeratne \& Stewart, 1970), there was no apparent difference in the results from the two breed groups in the present work. It is clear from this study that not all 'infertile' dairy cattle are incapable of breeding. The overall 'live' conception rate was $28 \%$, and more animals (e.g. the 4 mature and 4 young cows with a normal genital tract but served only once) might have conceived had further services been possible. However, statistical analysis of the proportions of animals with live embryos at slaughter in the two 'infertile' groups suggests that young animals are more likely to be able to conceive than the older cows ( $43 \%$ versus $19.6 \%, \chi^{2}=5.04,1$ d.f., $P<0.05$ ).

The present results suggest that infertility of immature cattle on farms is often only temporary. Skeletal growth in cows is not complete before 4-5 years of age (Davis \& Hathaway, 1958) and it seems possible that early first calving could be followed by a suspension of reproductive function until the metabolic demands of growth have been satisfied. For example, one animal, not included in this study, was received as a discard after a first lactation lasting only 3 weeks following the birth of a 9-kg calf (normal $35 \mathrm{~kg}$ ) and no subsequent service attempt. Under observation, this cow successfully produced a healthy full-sized calf, with lactations of normal size, in 2 succeeding years.

The results of the 'control' animals in this study also suggest a relationship between infertility and metabolism. The low milk yields of 9 of these cows may indicate poor feed conversion, resulting in low input of dietary energy, and hence infertility (McClure, 1965, 1966).

The present results with the young 'infertile' dairy cattle resemble those of Donaldson (1971) with beef cattle of various ages, but suggest that when mature dairy cows fail to breed, the infertility is more likely to be permanent and is often associated with the activity of pathogens. The structural lesions of the uterus and oviducts of the cows in this study are of a type known to be attributable to Corynebacterium pyogenes (Dawson, 1960; Rommel, 1961). Lovell (1943) has postulated an 'X-factor' as potentiating the pathogenicity of this organism: poor feed conversion, stress from successive closely-spaced lactations over a period of years, and skeletal immaturity could all contribute to such an 'X-factor' (Dawson, 1960).

\section{References}

BeYnon, V.H. \& Howe, K.S. (1974) The Disposal of Dairy Cows in England and Wales 1971-3. Univ. Exeter, Agric. Economics Unit, Report No. 192.

DAvid, J.S.E., Bishop, M.W.H. \& Cembrowicz, H.J. (1971) Reproductive expectancy and infertility in cattle. Vet. Rec. 89, 181-184.

Davis, H.P. \& Hathaway, I.L. (1958) Studies of growth in Holstein, Ayrshire, Guernsey, and Jersey females. J. Dairy Sci. 41, 745.

DAwson, F.L.M. (1958) The diagnosis and significance of bovine endosalpingitis and bursitis. Vet. Rec. 70, 487-493.

DAwson, F.L.M. (1960) Bovine endometritis, a review. Br. vet. J. $116,448-466$.

DAwson, F.L.M. (1963) Uterine pathology in bovine infertility. J. Reprod. Fert. 5, 397-407.

DAwson, F.L.M. (1972) Immaturity in relation to the discard of dairy cattle because they have not bred. Proc. 7th. Int. Meeting on Diseases of Cattle, London, pp. 468-475. Congress Office, World Ass. for Buiatrics, London.

DonaldSon, L.E. (1971) Investigations into the fertility of Brahman cross-bred female cattle in Queensland. Aust. vet. J. 47, 264-267.
Gunter, J.J., Collins, W.J., Owen, J., Sorensen, A.M., SCALES, J.W. \& ALFORD, J.A. (1955) A survey of bacteria in the reproductive tract of dairy animals. Am. J. vet. Res. 16, 282-285.

LOVELl, R. (1943) The source of Corynebacterium pyogenes infections. Vet. Rec. 55, 99-100.

MCCluRe, T.J. (1965) Experimental evidence for the occurrence of nutritional infertility in otherwise clinically healthy pasture-fed lactating dairy cows. Res. vet. Sci. 6, 202-208.

MCClure, T.J. (1966) Hypoglycaemia, a possible cause of mammalian female infertility. Aust. vet. J. 42, 308-310.

ROMMEL, W. (1961) Pathogenicity of Corynebacterium pyogenes in genitalia of cyclic cows. Proc. 4th Int. Congr. Anim. Reprod. \& A.I., The Hague, Vol. 3, pp. 503-510.

SMITH, G.F. (1958) The extent and scope of an artificial breeding programme for cattle. Vet. Rec. 70, 10891095.

SMITH, G.F. (1969) Evaluating recent movements in the dairy industry. Vet. Rec. 84, 388-390.

Wijeratne, W.V.S. \& StewarT, D.L. (1970) Stillbirths in cattle. Br. vet. $J .126,238-253$. 